\title{
The Influence of Urea Modified Lignin from Palm Empty Bunch toward Vegetative Aspects of Lettuce Leaves
}

\author{
Lucy Arianie, Ahmad Mulyadi, Wan Arif Abidin, Indra Johansyah Alam, and Afghani Jayuska
}

\begin{abstract}
Modified of urea fertilizer with lignin's palm empty bunch was applied to lettuce growth. This research aims to enhance the utility value of lignin from palm empty bunch, investigate slow release of urea-lignin fertilizer and vegetative aspect of leaves lettuce after period of week. Application of fertilizer was done in two difference places, namely green house laboratory and traditionally environment. Research showed that fertilized using urea fertilizer which modified by $2 \%$ of lignin resulted amount $(\mathrm{pc})$, length $(\mathrm{cm})$ and wide $(\mathrm{cm})$ of lettuce leave is better than fertilized only by urea in laboratory scale. Amount (pc), length $(\mathrm{cm})$ and wide $(\mathrm{cm})$ average of fresh lettuce leaves using urea modified by $2 \%$ lignin resulted 8 pieces, 12 $\mathrm{cm}$ and $11 \mathrm{~cm}$ respectively on 6 weeks after plantation. Furthermore in traditionally environment, amount (pc), length (cm) and wide average $(\mathrm{cm})$ of fresh lettuce leaves by using urea modified $3 \%$ lignin resulted 14 pieces, $25 \mathrm{~cm}$ and $21 \mathrm{~cm}$ consecutively on 6 weeks after plantation.
\end{abstract}

Index Terms-Lignin, lettuce, palm empty bunch, urea.

\section{INTRODUCTION}

Palm empty bunch (PEB) is a solid waste biomass from palm farming. The primary component of palm empty bunch is lignin and cellulose. Lignin is widely used based on structure, chemical characteristics and its abundances [1]. Lignin is a hydrofob polymer fenolic with non toxic fenilpropanoid monomer. On the contrary, urea is nitrogen fertilizers that hydrofil and easily dissolved in water. In general, urea fertilized repeatedly to makes the process of urea absorption by the plants' root is optimal. Modification of urea - lignin fertilizers was done to make slow release urea fertilizer.

\section{METHOD}

\section{A. Preparation of Sample}

Palm empty bunch was taken from Pabrik Minyak Sawit, PTPN XIII, Kabupaten Parindu, Kalimantan Barat, Indonesia This sample was prepared by heated under sunlight and

Manuscript received May 23, 2013; revised July 25, 2013. This work was financially supported by DP2M Direktorat Jenderal Pendidikan Tinggi, Republik Indonesia through Hibah Bersaing.

Lucy Arianie and Afghani Jayuska are with the Universitas Tanjungpura, Department of Chemistry, Faculty of Mathematics and Natural Sciences. Pontianak, Indonesia (e-mail: lucy.arianie@gmail.com, ganipontianak05 @yahoo.co.id).

Ahmad Mulyadi is with the Universitas Tanjungpura, Department of Agronomy, Faculty of Agriculture, Pontianak, Indonesia (e-mail: achmadm@yahoo.com).

Wan Arief Abidin is with the PT. Bank Mandiri (Persero), Sambas District, Indonesia (e-mail: wanarif05@gmail.com).

Indra J. Alam is with the PT. Sucofindo (Persero), Pontianak, Indonesia (e-mail: indrajohansyah@gmail.com). milled. All chemical which used are pro analysis grade except urea, then all procedures below was done triplo.

\section{B. Extraction of Lignin}

Palm empty bunch (PEB) was dried on the temperature $100-105^{\circ} \mathrm{C}$ for 4 hours. Extraction of lignin was done using reflux equipment which $50 \mathrm{~g}$ PEB, ethanol : water $(1: 1 \mathrm{v} / \mathrm{v})$ as solvent, $6 \% \mathrm{NaOH}$ at $180{ }^{\circ} \mathrm{C}$ for 60 minutes [2]. Ratio of PEB - solvent $=1: 10 \mathrm{w} / \mathrm{v}$. This process which called organosolv delignification will create two products namely pulp and black liquor. Lignin extracted by added water into black liquor (water : black liquor $=1: 6 \mathrm{v} / \mathrm{v}$ ). Then, the acidity was done by add $10 \% \mathrm{H}_{2} \mathrm{SO}_{4}$ up to $\mathrm{pH} 2$, heated up to $60{ }^{\circ} \mathrm{C}$ and stirred with magnetic stirrer. The sedimentation process occured for 4 hour. The product was filtered by whatman paper 42. Residu was washed using aquades $\mathrm{pH} 2$ and filtered vaccum again. This step were done for four times. The solid material namely lignin extract, was dried at $60{ }^{\circ} \mathrm{C}$ for 10 hours then stored in dessiccator [3].

\section{Purity Analysis}

The lignin extract was analyzed of its purity through gravimetric Klason method, by put $0.25 \mathrm{~g}$ of dry lignin extract in the beaker glass to the oven tempered $105^{\circ} \mathrm{C}$ for 4 hours. The lignin then dissolved into $15 \mathrm{~mL}$ of $72 \%$ sulfuric acid. Beaker glass is closed by the watch glasses for 2 hours then diluted by $400 \mathrm{~mL}$ of aquades. The reflux process was done up to 4 hours, filtered by filter funnel with fixed weight and residu washed until acid free [4]. The lignin residu was dried in the oven tempered $105^{\circ} \mathrm{C}$ for 4 hours, then kept in the desiccator. This lignin residu called pure lignin and measured. Percentage of the lignin purity was formulated as follows :

$$
\% \text { of purity lignin }=\frac{\text { Weight } \text { of pure lignin }}{\text { Weight } \text { of dry lignin }} \times 100 \%
$$

\section{Infra Red Measurements}

The analysis of functional group in lignin extract was determined by infra red spectrometer through pellet $\mathrm{KBr}$ method.

\section{E. Tablet of Urea - Lignin}

Tablet of urea - lignin made with the total weight of tablet was $850 \mathrm{mg}$. The process binding urea - lignin was done with the percentage 1,2,3,4 and $5 \%$ of lignin from the total weight of the tablet [5]. Kjehdal method are used to analizing nitrogen concentration of each tablet.

\section{F. Solubility Tablet Analysis}

Solubility tablet was analyzed using the modified glass tools that runs the water continually through the tablet. 
Stopwatch was used to investigate the time of tablet solubility. Rate of water flow is fixed $0.15 \mathrm{~m}^{2} /$ second [5], [6].

\section{G. Germination of Seed}

Various consideraton in choosing lettuce as sample plant because the main product of lettuce is its leaves. Lettuce seeds was got from plant traditional market. Before it is planted, the seeds of lettuce are germinated. The plantation into the $5 \mathrm{Kg}$ of plastic bag was done after the plant reach the age of two weeks after the seeds are germinated.

\section{H. Fertilization and Grooming of Plant}

Lettuce's fertilizing was done two weeks after planting. Three fertilizer tablets were inserted into the hole soil which its depth is $5 \mathrm{~cm}$ and the distance between hole and the lettuce's stem is $5 \mathrm{~cm}$. The grooming covers watering and weeds preventing. Lettuce's watering was done twice a day, in bright weather. If it is raining, the watering will not be done. Weeds' prevention was done mechanically by pulling it out and repeatedly done once a week. Lettuce planting done in two methods, firstly in modified green house laboratory and the last is traditional environment.

\section{Number, Length and Wide of Leaves Measurement}

The number of leaves measurement was done manually. The measurement of leaves length and wide done by leaf area meter and manually with milimeter block paper.

\section{RESULT AND DISCUSSION}

\section{A. Extraction of Lignin}

Extraction of lignin is similar to organosolv hydrolysis that aims to delignification of black liquor selectively. The principal of organosolv hydrolysis is hydrolyzed hemicelluloses simultaneously and dissolution of lignin using organic solvent that produce residue of cellulose. The average of black liquor and crude fiber that produced from this process were $233.3 \mathrm{~mL}$ and $44.34 \mathrm{~g}$ respectively [5].

The process of lignin extraction was done by adding aquades into black liquor with ratio black liquor : aquades $=$ $1: 6(\mathrm{v} / \mathrm{v})$ meant to enhance the form of lignin sediment. The average of extract lignin that produced was 0.837 and purity $81 \%$.

\section{B. Infra Red Lignin Analysis}

Studied using ${ }^{13} \mathrm{C}$ showed that $p$-hydroxyphenyl $\alpha$-prophenol (trans- $p$-coumaryl alcohol), guaiacyl $\alpha$-prophenol (trans-p-conyferil alcohol) and syringil $\alpha$-prophenol (trans- $p$-cinapyl alcohol) [1], which symbolized with $\mathrm{H}, \mathrm{G}$ and $\mathrm{S}$ respectively are precursor and units of lignin framer.

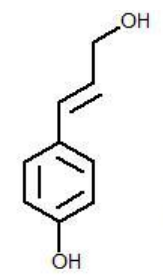

(a) $p$-coumaryl alcohol

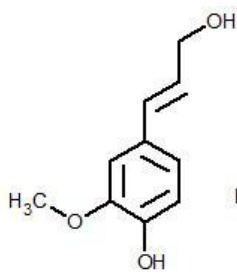

(b) conyferil alcohol

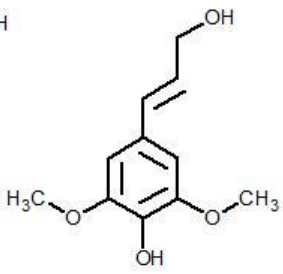

(c) cinapyl alcoho
Fig. 1. Monomer of lignin (modified from Fengel and Wegener, 1995)

The characteristics of extract lignin depends on the plant's species, geographic location and delignification process. Wood lignin generally contains monomer unit Guaiasil $(G)$ or Guaiasil - Siringil (G-S) [7]. Infra red spectrum of lignin and its explanation can be seen on Fig. 2 and Table I. Extract lignin consist of $\mathrm{G}$ monomer that explained at $1271.09 \mathrm{~cm}^{-1}$ and around $\sim 850 \mathrm{~cm}^{-1}$.

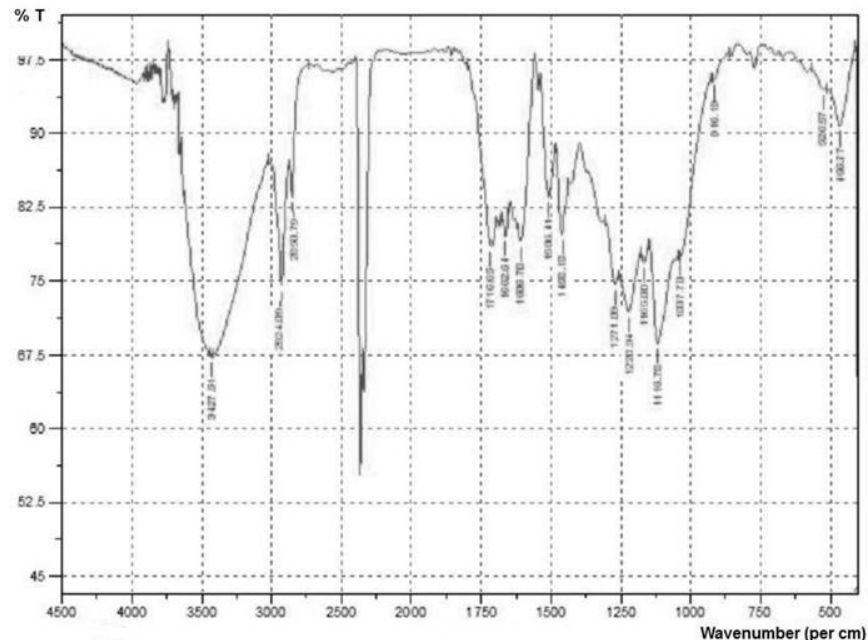

Fig. 2. Spectrum of infra red extract lignin

TABLE I: COMPARISON OF INFRA RED BANDTH OF STANDARD AND EXTRACT LIGNIN [5], [7]

\begin{tabular}{|c|c|c|}
\hline \multicolumn{2}{|c|}{ Bandth $\left(\mathrm{cm}^{-1}\right)$} & \multirow[t]{2}{*}{ Expalanation } \\
\hline $\begin{array}{l}\text { Extract } \\
\text { Lignin }\end{array}$ & Standard lignin & \\
\hline 1716.65 & $1738-1709$ & $\begin{array}{l}\mathrm{C}=\mathrm{O} \text { unconjugated keton in carbonil } \\
\text { or ester }\end{array}$ \\
\hline 1662.64 & $1675-1655$ & $\mathrm{C}=\mathrm{O}$ in aril - keton conjugated \\
\hline 1606.70 & $1593-1605$ & Aromatic vibration \\
\hline 1506.41 & $1505-1515$ & Aromatic vibration \\
\hline 1460.11 & $1460-1470$ & $\mathrm{C}-\mathrm{H}$ deformation (in $\mathrm{CH}_{2}$ or $\mathrm{CH}_{3}$ ) \\
\hline \multirow[t]{3}{*}{1458.18} & $1422-1430$ & $\begin{array}{l}\text { Aromatic vibration and } \mathrm{CH} \\
\text { deformation }\end{array}$ \\
\hline & $1365-1370$ & $\mathrm{CH}$ aliphatic in $\mathrm{CH}_{3}$ \\
\hline & $1325-1330$ & Ring $\mathrm{S}$ and $\mathrm{G}$. \\
\hline 1271.09 & $1266-1270$ & Ring $\mathrm{G}$ and $\mathrm{C}=\mathrm{O}$ \\
\hline 1220,94 & $1221-1230$ & $\mathrm{C}-\mathrm{C}, \mathrm{C}-\mathrm{O}, \mathrm{C}=\mathrm{O}$ \\
\hline \multirow[t]{2}{*}{1165.00} & 1166 & Specific for HGS lignin \\
\hline & 1140 & $\mathrm{C}-\mathrm{H}$ aromatic \\
\hline 1116.78 & $1125-1128$ & $\begin{array}{l}\text { Specific for unit } \mathrm{S} \text {; secondary alcohol } \\
\text { and } \mathrm{C}=\mathrm{O}\end{array}$ \\
\hline 1037.70 & $1030-1035$ & $\begin{array}{l}\mathrm{C}-\mathrm{H} \text { aromatic, } \mathrm{C}-\mathrm{O} \text { in primary } \\
\text { alcohol }\end{array}$ \\
\hline 916.19 & $915-925$ & $\mathrm{C}-\mathrm{H}$ (in aromatic ring) \\
\hline$\sim 850$ & $\begin{array}{l}853-858 \\
834-835 \\
817-832\end{array}$ & $\begin{array}{l}\mathrm{C}-\mathrm{H} \text { in position } 2,5,6 \text { (Unit } \mathrm{G} \text { ) } \\
\mathrm{C}-\mathrm{H} \text { in position } 2 \text { and } 6 \text { unit } \mathrm{S} \text { and all } \\
\text { unit unit } \mathrm{H} \\
\mathrm{C}-\mathrm{H} \text { in position } 2,5,6 \text { (Unit } \mathrm{G} \text { ) }\end{array}$ \\
\hline
\end{tabular}

\section{Lignin-Urea Tablet and Its Solubility}

Extract lignin from black liquor of palm empty bunch material is mixed by urea powder fertilizer and formed into tablet which its total weight reach $850 \mathrm{mg}$. Process of the binding lignin is done by the percentage 1, 2, 3, 4 and $5 \%$ from the total weight of tablet. The modification of commercial urea powder with lignin (variation percentage) is done to reduce the speed of urea dissolving. Solubility tablet was analyzed using the modified glass tools that runs the water continually through the tablet and rate of water flow is $0.15 \mathrm{~m}^{2} /$ second [5]. In this case, the tablet that has higher time is considered to have low speed solubility. Fig. 3 
demonstrated urea tablet and urea - lignin tablet. It can be seen that the more lignin bound to urea tablet, the more brown of tablet.

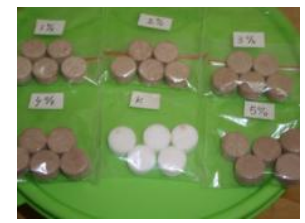

Fig. 3. Tablet of urea-lignin fertilizer.

Lignin - urea bound is able to increase the tablet's solubility time. Table II shows that urea tablet fertilizer bound with lignin $4 \%$ produces optimum tablet solubility time was 12.39 minutes. Meanwhile, the urea tablet fertilizer that is used to control fertilizer produces the tablet solubility time for 2.22 minutes.

\begin{tabular}{lc}
\multicolumn{2}{c}{ TABLE II: SOLUBILITY TIME OF TABLET FERTILIZER } \\
\hline \hline Treatment & Average of solubility time (minute) \\
\hline Urea & 2.22 \\
Urea-lignin 1\% & 1.36 \\
Urea-lignin 2\% & 1.77 \\
Urea lignin 3\% & 7.15 \\
Urea-lignin 4\% & 12.39 \\
Urea-lignin 5\% & 9.85 \\
\hline \hline
\end{tabular}

TABLE III: TOTAL NITROGEN IN TABLET FERTILIZER

\begin{tabular}{lc} 
Tablet fertilizer treatment & The average of total nitrogen $(\mathbf{g})$ \\
\hline Urea & 44.63 \\
Urea-lignin 1\% & 40.94 \\
Urea-lignin 2\% & 31.24 \\
Urea-lignin 3\% & 25.03 \\
Urea-lignin 4\% & 17.46 \\
Urea-lignin 5\% & 12.03 \\
\hline \hline
\end{tabular}

Reference [6] said, the use of lignin as the additional material in the urea tablet fertilizer has some advantages as follow :

1) Increase the economic value from the palm empty bunch waste by isolating lignin.

2) Lignin has a character which cannot be dissolved into water. If it is mixed with urea, the urea solubility will decrease and it will also decrease the nitrogen release so it can increase the efficiency in using urea fertilizer. It is worthed that plant will be able to absorb more nitrogen and grow optimally.

3) Lignin has the natural characteristics as the adhesive among the fiber, it means the bound power between urea and lignin will be stronger. When the mix of urea and lignin is formed into a tablet by using compression, lignin has a function to help the particle stick in the mix so the tablet fertilizer that made is stable. The urea lignin tablet fertilizer that produced is not fragile, not easily to crack and not easily soluble in water.

4) Lignin has non-toxic characteristic; it means lignin does not have bad impact to the environment. Lignin also can be found in the soil that comes from the residue of dead plant and unite with the soil. This means the use of lignin as the additional material in urea fertilizer does not affect the level of land fertility and plant's growth.

\section{Analysis of Nitrogen Concentration in Total Tablet}

The analysis of total nitrogen in each tablet produces various number. It shown in the Table III. It is assumed by the high weight of mass molecule lignin influenced the total weight of the tablets when it is weighted. Hygroscopic character of urea influence as well [5].

\section{E. Fertilization and Fertilizer Aspect}

The application of urea modified by lignin is done in lettuce which considered as a short term plant. It is applied repeatedly from 2009 to 2011 due to optimum observation.

This research using the lettuce's seeds branded 'panah merah' that assumed it has the same genetic factor and the process of photosynthetis is influenced by land, sunlight energy and fertilizer factors.

The growth of vegetative and production of plant depend on the interaction among the plant and environment condition where the plant grows. Condition of the environment is divided into climate, soil and other organism. These factors can limit or support the plant growth and production. Moreover, high production can be done by regulate the environment factors. One of the efforts to regulate the environment is by adding the fertilizer for vegetative growth.

Leaves is the main organ where the process of photosynthesis takes places. Reaction of photosynthesis illustrated as follows that Fig. out elements that affect its process:

$$
6 \mathrm{CO}_{2}+6 \mathrm{H}_{2} \mathrm{O}+\text { sunlight energy } \rightarrow \mathrm{C}_{6} \mathrm{H}_{12} \mathrm{O}_{6}+6 \mathrm{O}_{2}
$$

TABLE IV: THE INFLUENCE OF FERTILIZING TREATMENT TOWARD LETTUCE'S LEAVES AT FIRST CONDITION

\begin{tabular}{lccc}
\hline \hline Fertilizing treatment & \multicolumn{3}{c}{ at first condition 6 WAP*, average leaves : } \\
\cline { 2 - 4 } & Amount $(\mathrm{pc})$ & Length $(\mathrm{cm})$ & Wide $(\mathrm{cm})$ \\
\hline \hline 1. Without fertilizer & 6 & 5 & 5 \\
2. Urea & 7 & 10 & 10 \\
3. Urea - lignin 1\% & 8 & 10 & 10 \\
4. Urea - lignin 2\% & 8 & 12 & 11 \\
5. Urea - lignin 3\% & 8 & 10 & 10 \\
6. Urea - lignin 4\% & 8 & 8 & 8 \\
7. Urea - lignin 5\% & 8 & 7 & 9 \\
\hline \hline
\end{tabular}

*WAP $=$ Weeks after planting

TABLE V: THE INFLUENCE OF FERTILIZING TREATMENT TOWARD LETTUCE'S LEAVES AT SECOND CONDITION

\begin{tabular}{lccc}
\hline \hline Fertilizing treatment & \multicolumn{3}{c}{ at second condition 6 WAP*, average leaves : } \\
\cline { 2 - 4 } & Amount $(\mathrm{pc})$ & Length $(\mathrm{cm})$ & Wide $(\mathrm{cm})$ \\
\hline \hline 1. Without fertilizer & 8 & 10 & 10 \\
2. Urea & 12 & 18 & 10 \\
3. Urea - lignin 1\% & 12 & 18 & 13 \\
4. Urea - lignin 2\% & 12 & 20 & 17 \\
5. Urea - lignin 3\% & 14 & 25 & 21 \\
6. Urea - lignin 4\% & 15 & 24 & 18 \\
7. Urea - lignin 5\% & 14 & 22 & 19 \\
\hline \hline
\end{tabular}

$*$ WAP $=$ Weeks after planting

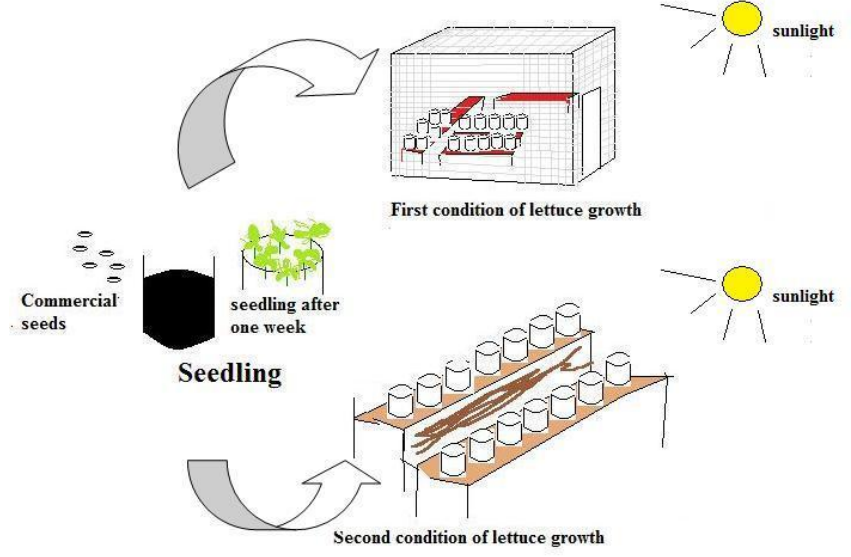

Fig. 4. Ilustration of urea modified lignin which applied to lettuce. 


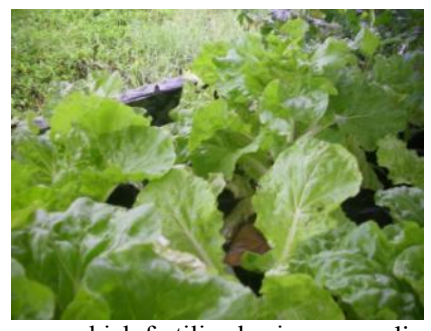

Fig. 5. Lettuce's leaves which fertilized using urea - lignin fertilizer in the second condition.

Stem of lettuce placed in the main centre and its leaves spread into stem caused the distribution of sunlight widespread throughout the leaves. Uniforms distribution of sunlight among the leaves will encourage leaves to photosynthesis.

The observed shows that the growth, numbers, length and wide of lettuce's leaves in modified green house laboratory are better by giving the urea tablet fertilizer modified by $2 \%$ lignin than using only the urea tablet fertilizer. Conversely, lettuce planting in traditional environment with urea tablet fertilizer which modified by $3 \%$ of lignin given better growth than planting in laboratory scale. It reach $21 \mathrm{~cm}$ of wide leaves average and $25 \mathrm{~cm}$ of length. It is clearly displayed in Table IV and Table V.

Fertilizing used urea fertilizer which modified by $2 \%$ and $3 \%$ of lignin are the optimum condition that can be seen on Table IV and Table V. Interestingly, there were significant differences between first and second condition of lettuce growth. It can be seen on Table 5 that second condition gives higher length and wide of leaves. It maybe caused by sunlight at the second condition optimally received by lettuce during its growth. Reference [8] shows that growth and production of plant, cannot be denied, depends on photosynthesis energy from sun. Closed green house tightly gives limited fresh air infiltration and carbon dioxide levels become reducing and affect for plant growth [8]. After all, it is assumed that urea fertilizer modified by 2-3\% lignin contains carbon (in the form of carbohydrate and chlorophyl) more than control lettuce.

\section{CONCLUSIONS}

This research must be tested repeatedly before applied to major plant cause there are lots of factor that influence vegetative factor of plant. Moreover, urea characteristics which higroscopics needs special handling when tablet binding.

\section{ACKNOWLEDGMENT}

This research has been done from 2008 - 2011, financially supported by DP2M Direktorat Jenderal Pendidikan Tinggi, Republik Indonesia through Hibah Bersaing scheme which contract number 023/SP2H/PP/DP2M/III/2008 and through DIPA Universitas Tanjungpura which its contract number 2215a/H22.12/PL/2009. We gratefully acknowledge for this precious opportunity.

\section{REFERENCES}

[1] D. Fengel and G. Wegener, Kayu: Kimia, Ultrastruktur, Reaksi-reaksi, Cetakan Pertama, Gadjah Mada University Press, 1995, pp.156-641.
[2] T. N. Kleinert, Organosolv Pulping with Aqueous Alcohol, TAPPI Journal, vol. 57, pp. 99-102, 1974

[3] L. Arianie, "Studi Pemanfaatan Lignin dan Lignosulfonat sebagai Aditif pada Perekat Fenol Formaldehid," M.Si. Graduate works, Dept. Chemistry, Institut Teknologi Bandung, Bandung, Bandung, Indonesia, 2002.

[4] Syahmani, "Isolasi, Sulfonasi dan Asetilasi Lignin dari TKS dan Studi Pengaruhnya Terhadap Proses Pelarutan Urea," M.Si. Graduate works, Dept. Chemistry, Institut Teknologi Bandung, Bandung, Bandung, Indonesia, 2001.

[5] L. Arianie, "Potention of lignin, lignin sulfonate and lignin acetate from palm empty bunch as an effort to reduce nitrogen solubility to environment," in Proc. Journal of Advanced Materials Research, Switzerland, 2010, pp. 409-412.

[6] W. A. Abidin, "Analisis Kelarutan Pupuk Tablet Urea Termodifikasi Isolat Lignin dari Tandan Kosong Sawit," S.Si. Thesis, Dept. Chemistry, Universitas Tanjungpura, Pontianak, Indonesia, 2009.

[7] X.-J. Pan and Y. Sano, “ Atmospheric acetic acid pulping of rice straw IV : physico-chemichal characterization of acetic acid lignins from rice straw and woods," Holzforschung, vol. 53, pp. 511-518.1999.

[8] D. Whiting, Plant Physiology: Photosynthesis, Respiration, and Transpiration, Colorado State University Extension, pp 141-1-141-4. 2011.

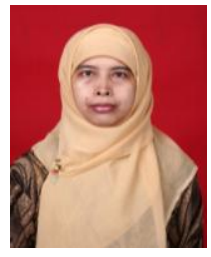

Lucy Arianie was born in Jakarta, Indonesia on January 29, 1975. Arianie was studied at Department of Chemistry, Universitas Sriwijaya, Palembang, Indonesia for bachelor degree (1998) and Institut Teknologi Bandung for Master degree (2002). She is now in doctoral degree at Institut Teknologi Bandung for related subject. She is worked as Lecturer at Universitas Tanjungpura, Pontianak, Indonesia since 2000. She interested in lignocellulose biomass especially from palm empty fruit bunch. Lucy Arianie, SSi., MSi., is member of Himpunan Kimia Indonesia.

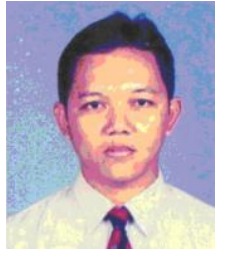

Ahmad Mulyadi was born in Bandung, Indonesia on March 13, 1966, Mulyadi was studied at Department of Biology, Universitas Padjadjaran Bandung for bachelor degree (1990) and Universitas Gadjah Mada Yogyakarta for Master degree (2004). He is worked as Lecturer at Universitas Tanjungpura, Pontianak, Indonesia.

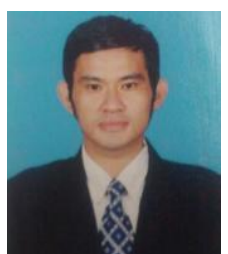

Wan Arief Abidin was born in Pontianak. Indonesia on May 26, 1986. Abidin was studied at the Department of Chemistry, Faculty of Mathematics and Natural Sciences, Universitas Tanjungpura in periods 2004-2010. He is now works with the PT. Bank Mandiri (Persero) Tbk., Sambas District, Indonesia.

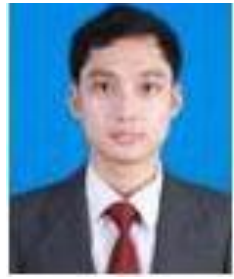

Indra Johansyah Alam was born in Pontianak, Indonesia on april 7, 1988. Alam was studied at the Department of Chemistry, Faculty of Mathematics and Natural Sciences, Universitas Tanjungpura in periods 2006-2011. He is now works with the PT. Sucofindo (Persero), Pontianak, Indonesia.

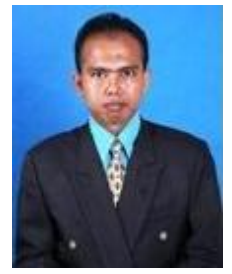

Afghani Jayuska was born in Pekanbaru, July 7 1971. Jayuska was studied at Department of Chemistry, Andalas University for bachelor degree (1996) and Institut Teknologi Bandung for Master degree (2001). He is worked as Lecturer at Universitas Tanjungpura, Pontianak, Indonesia. He interested in Natural Products Chemistry and microbial transformation of secondary metabolite. Afghani Jayuska, SSi., MSi., is member of The Indonesian Society of Natural Products Chemistry. 